\title{
ORGANIZATIONAL LEARNING IN CONSTRUCTION SUPPLY CHAINS
}

\author{
Author: this has been left blank until final editing
}

Address: this has been left blank until final editing

\begin{abstract}
Purpose - Learning within the supply chain is widely considered to provide the basis for enhanced competitive advantage. The purpose of this paper is to explore the theory and current practice of organizational learning in UK construction supply chains.
\end{abstract}

Design / methodology / approach - A qualitative research strategy is followed for this exploration of supply chain management and organizational learning. Research enquiry draws on semi-structured interviews with key construction supply chain stakeholders. The semi-structure interviews are recorded, transcribed and analysed via qualitative data analysis software.

Findings - Careful examination of the transcripts reveal that whilst supply chain management practice in construction is limited, key schools of organizational learning are similarly underdeveloped. Findings disclose construction supply chain organizations routinely employ learning strategies that are best described as reactionary and interventionist.

Research limitations / implications - Research was limited to the UK construction industry and encapsulates the assessment and evaluation of construction clients and first-tier supply chain members working within construction framework agreements. The perspectives of construction SME's were outwith the data set.

Practical Implications - Underdeveloped organizational learning practices within supply chains present a significant barrier to the development and diffusion of supply chain management theory and practice in construction. In practical terms, the attainment of competitive advantage and the development of competing supply chain in construction would be extremely limited.

Originality / value - Connecting organizational learning to the development and diffusion of supply chain management has been largely overlooked within the construction management literature. The research makes two notable contributions. First, the adaptation of a pragmatic and holistic organizational learning framework for the appraisal of learning strategies and second an evaluation of organizational learning in construction supply chains. 
Keywords: Supply Chain Management, Organizational Learning, Performance, Construction Industry.

\section{INTRODUCTION}

Organizational learning and supply chain management are two theoretical developments that are widely argued to contribute to organizational competitiveness (Sila et al., 2006, Bresnen, 2009). Over the past decade there has been significant interest in supply chain management theory and practice by construction management academics (Pryke, 2009, O'Brien et al., 2009), policy makers (Egan, 1998, Wolstenholme, 2009) and practitioners (Potts, 2009). Despite ongoing concerns regarding the diffusion of supply chain management in construction its relevance remains topical (Ellegaard et al., 2010, Segerstedt and Olofsson, 2010). Similarly organizational learning has also received considerable attention in organizational theory and construction management research (Chan et al., 2005). Although not mutually dependant, cultivating an organizational learning capability in the supply chain is argued to enhanced knowledge-sharing, innovation and competitive advantage (Love et al., 2002, Bessant et al., 2003, Mason and Leek, 2008).

Despite considerable academic and industry interest in organizational learning (Styhre et al., 2004), the diffusion of organizational learning in construction has proved problematic (Orange et al., 1999) and consequently underdeveloped in comparison with other sectors (Chinowsky et al., 2007b). Given this lack of development in construction, the concept of organizational learning within specific domains such as supply chain management remains largely overlooked. However, expanding the adaptation of organizational learning beyond traditional corporate boundaries is likely to disclose challenges and commercial opportunities, especially for temporary multiple organizations (TMO’s) (Stringer, 1967) in construction (Cherns and Bryant, 1984). Furthermore, given the growing environmental 
concerns and systemic lack of business confidence there is increasing pressure on construction stakeholders to better comprehend how organizational learning facilitates supply chain performance.

Arguments within the supply chain literature and wider community suggest that supply chain performance must be closely aligned with management concepts of culture (Fellows, 2009) quality (Love et al., 2004b) continuous improvement, best practice (Egan, 1998), innovation (Love et al., 2002) and organizational learning (Bessant et al., 2003, Bresnen, 2009). Organizational learning and the subsequent dissemination of knowledge are similarly argued to be instrumental in the pursuit of improved productivity and industry competitiveness (Spender, 1996). Connecting organizational learning with the practice of supply chain management in UK construction offers considerable promise.

The research adopts a framework of four discrete and mutually dependent schools of thought in organizational learning (Bell et al., 2002) to explore organizational learning in construction supply chains. The research is limited to supply chains within the context of construction framework agreements. Construction frameworks are argued to provide an opportunity to explore construction supply chain best practice. The main purpose of the paper is to empirically explore, develop and deepen understanding of organizational learning in construction supply chains.

The paper is organized in a conventional manner. Following the introduction, there is a broad critical review of supply chain management and organizational learning. Drawing from the review, four schools of organizational learning advocated by Bell et al (2002) are use to develop an organizational learning agenda. The next section provides an explanation and description of the research strategy adopted. The findings and discussion chapter discloses current trends regarding organizational learning in construction supply chains. In the final section, a number of conclusions are presented. 


\section{SUPPLY CHAIN MANAGEMENT}

Notwithstanding considerable academic study, a universally accepted definition of supply chain management remains elusive (Stock and Boyer, 2009). However, a rudimentary classification of supply chain management understanding discloses two very distinctive schools of thought; a functional school (Spekman et al., 1998) and a philosophical school (Cooper and Ellram, 1993). The functional school of thought maintains strong links with the founding principles of supply chain management and its close affiliation with purchasing, logistics and operations management (Lummus and Vokurka, 1999).

According to Cox (2006), the function of supply chain management is to perform as a sourcing strategy that will seek to leverage the best possible price from the current market conditions, via the most optimum procurement route (Spekman et al., 1998). This largely utilitarian strategy to supply chain management involves "the buyer undertaking proactive supplier development work not only at the first tier of the supply chain but also at all the stages in the supply chain from first tier through to raw material" (Cox et al., 2006 p.112).

Alternatively, Cooper and Ellram (1993) endorse a philosophical school of thought. The philosophical approach reaffirms many key features of the functional school as well as articulating tacit characteristics such as integrity, teamwork and professionalism. Proponents of the philosophical school however avoid explicit identification of specific supply chain management functions in favour a largely conceptual, abstract and arguably vague interpretations. Simply expressed, a philosophical school depicts supply chain management as 'a way of working'. According to Power (2005) the foremost ambition of supply chain management is to enhance performance, regardless of competing definitions (Tommelein et al., 2009). 


\section{SUPPLY CHAIN MANAGEMENT IN UK CONSTRUCTION}

In response to corporate dissagregation (Zenger and Hesterly, 1997) and ever-increasing levels of construction sub-contracting (Crespin-Mazet and Portier, 2010), supply chain management in construction has become ever more popular (O'Brien et al., 2009). Whereas traditional construction project practices are thought to inhibit learning (Kohtamaki, 2010), supply chain management is argued to stimulate innovative practice and promote organizational learning (Meng et al., 2011). Proponents of supply chain management are keen to highlight the business opportunities for organizations to capture, interrogate and transfer supply chain efficiencies on to other projects. Key benefits include, cutting construction waste (Dainty and Brooke, 2004), building trust (Kumaraswamy et al., 2008) and driving down transactional costs (Korczynski, 1996, Cox et al., 2006).

Developing theory and practice from other industries to achieve these key benefits in construction requires “careful translation" (Skitmore and Smyth, 2009 p.97). In an attempt to connect supply chain management theory rooted in manufacturing and supply chain management in construction, Vrijhoef and Koskela (2000) identified a number of discrete roles;

* the operational interface between construction contractor and construction subcontractors

* the operational capacity of the upstream supply chain

* transferring onsite construction activity, offsite

* creating a fully integrated and extended management of the supply chain

* the role of the construction client and their prominence in driving improvements in construction supply chain management. 
Whilst subsequent construction studies (c.f. Dainty et al., 2001, Khalfan and McDermott, 2007, Doran and Giannakis, 2011) have explored in detail the practical implications of the roles identified by Vrijhoef and Koskela (2000), the influence of the construction client dominates recent industry interest in supply chain management (King and Pitt, 2009). Construction clients, especially those with significant capital expenditure can exert substantial influence on working relationships, in particular their commercial relationships with first-tier construction service and product providers. Consequently, the role of the construction client on the management of the supply chain has become increasingly distinctive.

Supply chain management driven by the construction client differs significantly from a contractor-led supply chain orientation. First, a client-led supply chain has a clearly identifiable project focus (Skitmore and Smyth, 2009) and second, given the inherent nature of construction projects the client-led supply chain remains temporary. Recent developments in client-led supply chain management are largely reflected in relational procurement routes such as construction framework agreements. Industry figures reveal over two hundred construction framework agreements currently operational in the UK public sector (Chevin, 2011).

Notwithstanding the recent dominance of client-led supply chain management, the importance of subcontracting in construction is readily acknowledged (Vrijhoef and Koskela, 2000, Dainty et al., 2001). In contrast to client-led supply chain arrangements, the contractorled supply chain is driven by the construction contractor and has no specific client affiliation. Previous studies suggest construction firms that frequently sub-contract, typically work with only a few select sub-contractors (Eccles, 1981, Gosling et al., 2010). Two familiar characteristics continue to govern contractor-led supply chain management. First, price remains the prevailing consideration for sub-contractor selection (Hartmann and Caerteling, 
2010) and second rarely does the contractor-led supply chain extend beyond second tier suppliers or sub-contractors (Saad et al., 2002).

Despite the fragmented and characteristically short construction supply chain structure(s) (Skitmore and Smyth, 2009), supply chain management practice is central to relational forms of procurement such as framework agreements. Framework agreements typically capture both the client-led and contractor-led supply chains and therefore present an unparalleled opportunity to explore supply chain management best practice in UK construction. Within framework agreements, the development and diffusion of organizational learning is also connected to supply chain practice and performance. Consequently, the mechanisms for organizational learning need to be firmly embedded within the existing short supply chain structures and beyond. This is arguably one of the greatest challenges to the creation of commercially viable and socially enduring supply chain management practice in construction.

\section{ORGANIZATIONAL LEARNING}

Since the 1990's organizational learning has witnessed growing acceptance within the business community (Styhre et al., 2004). As a result, an increasing number of studies have explored organizational learning and the potential contribution of organizational learning as a source of competitiveness (Martinez-Costa and Jimenez-Jimenez, 2009). However, there is little conceptual consensus (Easterby-Smith and Araujo, 1999).

Levitt and March (1988 p.320) define organizational learning “as learning by encoding inferences from history into routines that guide behaviour". Other theorists have drawn upon and reinforced the requirement to debate divergent as well as analogous domains of organizational learning. The ensuing conceptual dissonance within the theory of 
organizational learning supports many perspectives rooted in processes (Easterby-Smith and Araujo, 1999) disciplines (Senge, 1990) and dimensions (Huber, 1991). What has emerged is the need to consider organizational learning from disparate schools of thought; an economic school, a developmental school, a managerial school and a process school (Bell et al., 2002).

Expanding on Bell et al's (2002) schools of thought in organizational learning, the 'economic school of thought' is largely representative of the learning curve. Drawing on facets of organizational routine and history (Levitt and March, 1988), the learning curve reflects the idea of learning and acquiring knowledge through discovery. The economic school of organizational learning is focused on encoding inferences and understanding that accrue from the repetitive action and subsequent reaction that occur with continuous production. This approach to learning capitalizes on the "detection and correction of errors" (Argyris, 1977 p.120) Cognitive development is usually immediate and directly related to a set of specific circumstances. In terms of learning capacity, the majority of learning may be classified at the lower-end of the learning taxonomy (Bell et al., 2002).

Organizational learning that takes place as a direct result of management-led intervention is called the 'managerial school of thought'. In contrast to the economic school of thought, the managerial school of thought addresses higher order learning (Bell et al., 2002). However, the adhoc delivery of management-led training arguably dilutes the potential value of the learning experience. Very often managerial intervention is a carefully calculated corporate reaction to changing circumstances. For example in response to progressive health and safety legislative requirements, employees may require additional professional development. Organizing management-led training events will provide a formal forum for companies to address changing policy and operational practice. According to Kululanga et al (2001 p.23) this reactionary and interventionist approach to organizational learning may be described as “forced organizational learning”. 
In sharp contrast to the unstructured, management-led approach to organizational learning; the 'developmental school of thought' although arguably similar in educational content, delivers training via carefully composed and logically structured educational frameworks. As a result "learning proceeds in a series of interlinked sequences that provide the necessary foundation for moving to each successive stage” (Bell et al., 2002 p.71). Each stage of the education experience represents an incremental development of individual learning and organizational capability. Structured trade-based apprenticeships and professional accreditation programmes are largely reflective of a developmental school of organizational learning. Building carefully on the foundation of previous knowledge arguably enhances the cognitive evaluation of existing concepts and schemata.

Finally, the 'process school of thought' represents all learning 'processes' that stimulate knowledge creation, knowledge sharing and co-production. Not dissimilar to Huber's (1991) four mutually dependent dimensions; knowledge acquisition, information distribution, information interpretation and organizational memory, the process school of organizational learning is refined around the efficient management of knowledge and the interrelated processes of acquisition, organization and dissemination of information. In construction this could be reflective of intranets (organization and project based), project planning, scheduling and formal meetings. It could be argued that the process school of organizational learning is in essence a knowledge management and communication exercise. However, the efficiency of transmission and quality of learning material does not automatically increase the receivers ability to learn (Huber, 1991). According to recent research, personal motivation remains central to learning (Ringberg and Reihlen, 2008).

In summary, Bell et al's (2002) schools of thought in organizational learning represent a pragmatic and holistic framework for the exploration of organizational learning in UK construction supply chains (see Table 1.). 


\begin{tabular}{|c|c|c|c|c|}
\hline $\begin{array}{c}\text { Schools of } \\
\text { Thought: }\end{array}$ & $\begin{array}{c}\text { Economic } \\
\text { School }\end{array}$ & $\begin{array}{c}\text { Managerial } \\
\text { School }\end{array}$ & $\begin{array}{c}\text { Developmental } \\
\text { School }\end{array}$ & $\begin{array}{c}\text { Process } \\
\text { School }\end{array}$ \\
\hline Action: & Learn by & $\begin{array}{c}\text { Learn Led by } \\
\text { Discovery }\end{array}$ & $\begin{array}{c}\text { Evolution of } \\
\text { Learning }\end{array}$ & $\begin{array}{c}\text { Learning } \\
\text { Environment }\end{array}$ \\
\hline Generic & Refine Practice \\
Example: & $\begin{array}{c}\text { Training / } \\
\text { / Continuous } \\
\text { Production: } \\
\end{array}$ & $\begin{array}{c}\text { Sponsontions by } \\
\text { the } \\
\text { The Learning } \\
\text { Curve }\end{array}$ & $\begin{array}{c}\text { Organization } \\
\text { Educational } \\
\text { Programme } \\
\text { Sponsored by } \\
\text { the } \\
\text { Organization }\end{array}$ & $\begin{array}{c}\text { Organizational } \\
\text { Mechanisms } \\
\text { for Information } \\
\text { Acquisition, } \\
\text { Dissemination } \\
\text { and Utilization }\end{array}$ \\
\hline
\end{tabular}

Table 1. Schools of Thought in Organizational Learning (Bell et al., 2002).

\section{ORGANIZATIONAL LEARNING IN CONSTRUCTION}

Although previously thought to be largely the preserve of knowledge based industries, the transformation of construction companies towards a learning organizational culture has gained momentum in recent years (Chinowsky et al., 2007a). According to Chinowsky et al (2007b p.28) "the primary driver for implementing a learning organization is the need to remain competitive in the new knowledge era through the delivery of knowledge-based solutions that better meet the needs of clients". Given the dynamic competitive pressures of an emergent knowledge economy (Adler, 2001), the challenge for construction firms is to pro-actively promote organizational policies, procedures and practices that explore and exploit knowledge creation to cultivate a sustainable learning agenda (Kululanga et al., 2001).

In the construction sector it is important that the practices implemented by key supply chain members share a common purpose (Peters et al., 2010). Unlike the automotive / retail industries that exhibit largely unilateral relationship characteristics, the construction industry is multiparty. As a result of the diverse and often complex power relationships (Cox, 2004), construction performance is dependent upon loosely coupled and short supply networks. Establishing mutual understanding and trust within supplier networks has long been a central 
concern for the management and success of co-learning (Orange et al., 1999) and effective supply chain management (Love et al., 2004a).

Despite the commercial benefits of organizational networking (Westerlund and Rajala, 2010), it has arguably only been in the wake of 'Rethinking Construction' (Egan, 1998) that the construction sector has begun to establish robust learning metrics for the management of continuous improvement and performance measurement programmes. Nonetheless, many barriers continue to impede the concept of organizational learning in UK construction; most significantly, the necessity to cultivate a co-learning culture throughout the supply network. A successful supply chain learning agenda in UK construction requires multi-lateral participation. This is a considerable challenge for an industry widely denounced for propagating a culture of blame, self-interest, conflict and opportunism. This is particularly pertinent given the urgent need to delivery legally binding low-carbon infrastructure (BIS, 2010).

\section{RESEARCH STRATEGY}

A qualitative research strategy was followed for this exploration of organizational learning in construction supply chains. In contrast to mainstream positivism paradigms of cause and effect, the aim of an interpretative approach is to interrogate practitioner understanding and disclose discrete learning processes (Orton, 1997). It is argued that construction organizations do not have a cognitive ability to learn (Green, 2011); organizational learning is facilitated by learning undertaken by individuals (Love et al., 2004b). Consequently it is important via a process of qualitative analysis to comprehend the experiential relationship between the individual, the organization and the community of supply chain members. 


\section{Data Collection}

Data collection focuses on seven organizations, each with a vested concern in construction framework agreements. The seven participating companies include; two client bodies, two first tier construction service providers and three construction contractors. Interviews were carried out between January 2011 and March 2011.

Originally a few construction sources where identified and approached for interview. During initial correspondence with informants, they where asked to recommend potential candidates thought suitable for inclusion. Via this "snowballing technique” (Green et al., 2010 p.120) additional participants were identified, contacted, appraised and subsequently invited to participate in the research programme. The seven organizations selected, where specifically chosen because of their direct involvement with either client-led supply chains, contractor-led supply chains or both.

The data set represents a close-knit 'community of supply chain members'. The "snowballing technique” (Green et al., 2010 p.120) used to recruit informants disclosed an unanticipated degree of both organizational and individual familiarity within the construction community. Informants revealed not only an acute awareness of supply chain co-members but also considerable knowledge of the activities and potential implications of competing supply chain companies. The apparent mutuality of many construction relationships was very much in evidence and consequently informed and characterized a research data set where the majority of participating organizations have a significant commercial investment in construction framework agreements.

In total, fifteen interviews were conducted on a one-to-one basis. Each interview was recorded with the explicit permission of the informant. The interview was subsequently transcribed verbatim and later analysed through qualitative analysis software package, NVivo 
version 8. The framework for codification and interpretative analysis was derived from the interview template (see table 2). Although the research strategy advocated a semi-structured interview technique, an interview template was thought necessary for two reasons. First the interview template would provide discipline and rigour to the interview procedure and second, act as an aide-memoir for the development of understanding grounded in multiple dimensions of organizational context, personal learning, organizational learning and supply chain learning.

\begin{tabular}{|l|c|c|c|c|}
\hline $\begin{array}{l}\text { General } \\
\text { Headings: }\end{array}$ & $\begin{array}{c}\text { Organizational } \\
\text { Context }\end{array}$ & $\begin{array}{c}\text { Personal } \\
\text { Learning }\end{array}$ & $\begin{array}{c}\text { Organizational } \\
\text { Learning }\end{array}$ & $\begin{array}{c}\text { Supply Chain } \\
\text { Learning }\end{array}$ \\
\hline Broad & Company & Personal & Organizational & Problem- \\
Themes: & History & Experience & Lolving \\
& Corporate & Personal & Organizational & Risk \\
& Structure & CPD & Culture & Evaluation \\
& Induction & Performance & Learning & Rewards \\
& Training & Relationships & Team Working & Collaboration \\
& Management & Reflective & Mechanisms of & Learning \\
& Style & Practitioner & OL & Curve \\
& ICT Facilities & Motivation & Examples & Interventions \\
& & & & \\
\hline
\end{tabular}

Table 2. Semi-Structured Interview Template: General Headings and Broad Themes

In addition, the interview template provided the basis for coding, analysis and subsequent arrangement of organizational learning schools adopted by construction stakeholders engaged in supply chain management.

\section{FINDINGS AND DISCUSSION}

Drawing on testimonies, a profile of organizational learning in UK construction supply chains has been compiled and classified in accordance with Bell et al's (2002) four schools of 
organizational thought (see Table 3.). Each school of thought has an important contribution to make, however over-emphasis of a particular school of thought at the expense of alternative schools is argued to diminish the overall impact of organizational learning (Bell et al., 2002).

\begin{tabular}{|c|c|c|c|c|}
\hline $\begin{array}{l}\text { Schools of } \\
\text { Thought: }\end{array}$ & $\begin{array}{l}\text { Economic } \\
\text { School }\end{array}$ & $\begin{array}{l}\text { Managerial } \\
\text { School }\end{array}$ & $\begin{array}{c}\text { Developmental } \\
\text { School }\end{array}$ & $\begin{array}{l}\text { Process } \\
\text { School }\end{array}$ \\
\hline Action: & $\begin{array}{l}\text { Learn by } \\
\text { Discovery }\end{array}$ & $\begin{array}{l}\text { Learn Led by } \\
\text { Management }\end{array}$ & $\begin{array}{l}\text { Evolution of } \\
\text { Learning }\end{array}$ & $\begin{array}{c}\text { Learning } \\
\text { Environment }\end{array}$ \\
\hline $\begin{array}{c}\text { Examples of } \\
\text { Organizational } \\
\text { Learning in } \\
\text { Construction } \\
\text { Supply Chains: }\end{array}$ & $\begin{array}{l}\text { Supply Chain } \\
\text { Forums, } \\
\text { Industry } \\
\text { Workshops \& } \\
\text { Learning Sets }\end{array}$ & $\begin{array}{c}\text { Contracts: } \\
\text { NEC3, Euro- } \\
\text { Codes, BIM } \\
\text { and Health \& } \\
\text { Safety }\end{array}$ & None & $\begin{array}{c}\text { ICT, BIM } \\
\text { Technologies } \\
\text { \& KPI Based } \\
\text { Performance } \\
\text { Appraisals }\end{array}$ \\
\hline $\begin{array}{l}\text { Mechanism of } \\
\text { Organizational } \\
\text { Learning in } \\
\text { Construction } \\
\text { Supply Chains: }\end{array}$ & $\begin{array}{c}\text { Think-Tank / } \\
\text { Single Loop } \\
\text { Learning }\end{array}$ & $\begin{array}{c}\text { Operational / } \\
\text { Adaptive } \\
\text { Learning }\end{array}$ & $\begin{array}{c}\text { Anticipatory / } \\
\text { Double Loop } \\
\text { Learning }\end{array}$ & $\begin{array}{l}\text { Strategic / } \\
\text { Generative } \\
\text { Learning }\end{array}$ \\
\hline $\begin{array}{l}\text { Mode of } \\
\text { Learning: }\end{array}$ & Reactive & Interventionist & Synthesis & Pro-active \\
\hline $\begin{array}{l}\text { Frequency of } \\
\text { Practice: }\end{array}$ & $\begin{array}{l}\text { Routine } \\
\text { Practice: }\end{array}$ & $\begin{array}{l}\text { Regular } \\
\text { Practice: }\end{array}$ & $\begin{array}{l}\text { Disregarded } \\
\text { Practice: }\end{array}$ & $\begin{array}{l}\text { Developing } \\
\text { Practice: }\end{array}$ \\
\hline
\end{tabular}

Table 3. Organizational Learning in Construction Supply Chains.

\section{Economic School of Learning}

Analysis of informant testimonies clearly demonstrate that the economic school of organizational learning, typified by the notion of 'the learning curve' remains the dominant organizational mechanism for knowledge acquisition in UK construction. Informants from across the seven companies made repeated reference to concepts of lessons learnt and the learning curve. Whilst the majority of construction project know-how acquired via the learning curve appear to remain largely tacit and unstructured, subtle changes in organizational policy, procedure and custom disclosed preliminary attempts at capturing and sharing key facets of experiential project learning. Many of these developments are driven by 
'best practice' and key performance indicators (KPI’s). However, the discernible purpose of KPI’s was to identify and correct sub-optimal construction performance.

Learning about new technologies, systems of organization and project performance utilized a clearly identifiable organizational strategy namely; supply chain forums, industry workshops and/or learning sets. Although the transfer of knowledge displayed elements of a process school of thought, organizational learning about alternative systems of working remained rooted in the economic school of thought. The community of supply chain 'learners' (forums, workshops and learning sets) continue to identify, disseminate and share project knowledge based upon previous experience and given the apparent lack of root cause analysis; intuition. Capturing experiential learning via newly established supply chain symposia is simply the process school facilitating classic concepts of trial and error. These supply chain 'think-tanks' have arguably engendered stronger commercial and social bonds. However, contrary to any refinement in the diffusion of construction practice, the mechanism for organizational learning in supply chains remains entrenched in ‘learn by discovery’ routines.

Construction in the UK has a recent history of Government sponsored 'learning by discovery'. Demonstration projects were a key component of the post Egan 'change agenda' (Olayinka and Hedley, 2007). According to Garvin (1993 p.83), demonstration projects only have limited impact on organizational approaches (and by extension construction industry practice) if unaccompanied by "explicit strategies for transferring learning”. Demonstration projects (economic school of thought) devoid of compensatory schools of thought (managerial, developmental and process) will result in insufficient scrutiny and analysis. Consequently, organizations relying exclusively on experiential learning may only succeed in becoming increasingly inefficient and potentially incompetent. Despite this caveat, learning from a programme of demonstration projects is not inappropriate. 'Learning by discovery' 
should however, only represent one constituent of a holistic approach to organizational learning in the construction supply chain.

\section{Managerial School of Learning}

The introduction of a 'forced' programme of organizational learning, according to Kululanga et al (2001) is a corporate reaction to perceived threats. Management-led training in construction organizations is largely motivated by prevailing environmental circumstances. Testimonies demonstrate three examples of management-led intervention driven by changing contractual, legislative and technological circumstances.

The first example of 'forced learning' was contractual and involved the majority of participating companies. Management-led instruction relating to relational forms of contract such as the New Engineering Contract version 3 (NEC3) was motivated by the increasing popularity of construction framework agreements (RICS, 2010) and use of NEC forms of contract. Competence in NEC3 is arguably driven by corporate anxiety and the necessity to understand the NEC3 'rules of engagement'. Company failure to fully comprehend the complexities and risk associated with previously unfamiliar forms of contractual governance such as NEC3 could ultimately results in costly delays, disputes and a tarnished reputation.

The second example was legislative and referred directly to informants working for a firsttier specialist engineering organization. Respondents made reference to management sponsored training in preparation for the introduction of new BS Structural Euro-codes. Not dissimilar to NEC3 training, organizational learning was again driven by perceived threats. Failure to comply with newly introduced legislative standards may be severely punished by EU and UK regulatory bodies. In addition, non-compliance with strict legislative requirements would in likelihood veto further involvement in client-led framework agreements and their supply chain. 
The third example of 'forced' organizational learning involved a first-tier specialist design organization. Management-led training focused specifically on the introduction of Building Information Modelling (BIM) technologies. Company training on the use and application of 'Revit' (a specialist, architectural software package designed to improve coordination and collaboration across the supply chain) was undertaken exclusively in-house by knowledgeable employees. Whilst specialist training in BIM software was restricted to firsttier design consultants, it was evident from discussions that the emergence of BIM technologies had a potential operational value for construction clients and contractors alike.

Regardless of organizational motivation, knowledge of BIM technologies was again largely driven by corporate anxiety. To ignore industry developments in BIM may ultimately undermine the operational expediency of an organization and subsequently compromise the efficient management of the supply chain. In addition, to overlook the introduction of BIM may permit companies to challenge the operational legitimacy of a competitor. Given the commercial pressure to secure future supply chain membership with construction clients, embracing BIM technologies is an important and potential advantageous strategy for organizations and supply chains. Given the impending legal requirement to accept BIM technologies, the future legitimacy of supply chain members within public sector framework agreements will be assured.

\section{Developmental School of Learning}

Evidence from across the first-tier and clients organizations has already highlighted the reactionary and interventionist default learning strategies routinely adopted. In contrast to the refined economic and managerial schools, a developmental school of organizational learning in UK construction would appear to be disregarded. Informants, representing construction organizations failed to cite any construction related examples of carefully structured training programmes specifically designed to deliver incremental learning opportunities for 
individuals, organizations and supply chain members. Whilst it may be reasonable to suggest a construction professional is responsible for their personal professional development, there would appear to be a lack of vision and post-university educational infrastructure.

The revelation is potentially significant. The absence of a developmental school of thought highlights the endemic lack of investment in training, education and research in construction. There are potential reasons for the complete lack of structured training programmes, including the current economic correction. However, continued failure to invest in the intellectual capital of the professional workforce will severely inhibit organizational learning in the supply chain. Although beyond the scope of this paper, organizational learning has significant implications for construction companies and the future challenge of managing social capital (Bresnen et al., 2005).

\section{Process School of Learning}

Despite the lack of a developmental school of organizational learning in construction, there was evidence of an emergent process school of thought. Quintessentially a communication exercise, mechanisms for knowledge transfer among supply chain members was arguably enhanced by increasing software compatibility and the developing use of BIM technologies. Whilst ICT integration creates a newfound technological environment highly capable for efficient knowledge acquisition and sharing, the social environment remains just as important. Interestingly, informants displayed an awareness of the social dynamics and many acknowledged that within supply chain alliances information sharing was improving. Within a progressive social structure the potential for BIM technology is significant; however, there was evidence to suggest that outwith such a structure BIM could exacerbate problems of collaboration and supply chain integration regardless of technological advances. 
It is naive to suggest the role and potential influence of organizational learning in supply chain management is wholly dependent upon the capability and capacity of its members. The current economic climate unsurprisingly and justifiably created considerable anxiety for many informants. Even industries with a history of successful supply chain management it is inevitable that during periods of economic hardship suppliers are subjected to cost cutting measures (Blake et al., 2003). Consequently, supply chain management practice and the prevailing reactive approach of organizational learning may in part be driven by "systemic uncertainty” (Boyd and Wild, 2003 p.81) in the construction sector.

There are signs of change. A recurrent theme was the initiation of supply chain forums, supply chain workshops and the sponsorship of supply chain learning sets. Whilst the forums, workshops and learning sets undoubtedly provided opportunities for sharing technological experiences and expertise in the quest for greater efficiency and effectiveness, the dedicated symposia also provide a unique social space. Given that organizational learning is a social phenomenon, as opposed to a solitary one; the creation of a unique social space in which to share and more importantly reflect on supply chain experiences is significant. The driver behind the process school of learning may be technological, but the reality is far more complex, dynamic and socially immersed.

In sum, the empirical evidence discloses an approach to organizational learning not dissimilar to the finding presented by Bessant et al (2003). Organizational learning in construction supply chains remains largely a product of project 'history', legislation (Barlow and Jashapara, 1998) and a victim of circumstantial development. Despite nearly a decade of development and diffusion, supply chain learning in construction remains at "an early stage" (Bessant et al., 2003 p.182). Many construction clients, contractors and suppliers are exploring contemporary organizational practices such as supply chain management, however traditional approaches to learning persist largely unchallenged. If supply chain members 
interpret new challenges employing old ways, substantive supply chain learning will fail to evolve (Love et al., 2004b). However given time, commitment and industry investment in education; supply chain management in construction may provide the catalyst for progressive learning strategies, tools and techniques.

\section{CONCLUSIONS}

The research makes two notable contributions. First, the adaptation of a pragmatic and holistic framework for the appraisal of organizational learning strategies in construction supply chains. Second, an analysis of current strengths, prevailing difficulties and prospective developments of a coherent, robust and persuasive supply chain learning agenda in UK construction.

Whilst acknowledging the necessity for a more comprehensive study, the research evidence discloses clearly identifiable trends. Testimonies from informants suggest frequent engagement with and refined levels of economic and managerial schools of organizational learning. In stark contrast, the developmental school of organizational thought remains disregarded, ill-defined and potentially problematic. The process school of thought although currently marginalized, disclosed an emergent and potentially significant technological advancement within the discipline of supply chain learning in construction.

Despite the cultural and structural challenges facing supply chain learning in UK construction, progress has arguably been made. The increasingly influential role of the serial construction client coupled with notable developments in ICT and BIM technologies have began to engender an inter-organizational dependency that was previously thought atypical of construction activity. Contemporary supply chains in construction reflect not only traditional economic interests but also increasingly social and technological alliances. 
The notion of a coherent and robust supply chain learning agenda offers considerable promise, however much remains to be done. Circumstantial factors impact upon and respond to construction industry enthusiasm for organizational learning within the supply chain. Given the current economic climate, the outlook for supply chain management and organizational learning in construction is arguably pessimistic.

\section{ACKNOWLEDGEMENT}

This has been left blank until final editing.

\section{REFERENCES}

ADLER, P. S. (2001) Market, Hierarchy, and Trust: The Knowledge Economy and the Future of Capitalism. Organizational Science, 12, 215 - 234.

ARGYRIS, C. (1977) Double loop learning in organizations. Harvard Business Review, 55, $115-126$.

BARLOW, J. \& JASHAPARA, A. (1998) Organisational learning and inter-firm "partnering" in the UK construction industry. The Learning Organization, 5, 86 - 98.

BELL, S. J., WHITWELL, G. J. \& LUKAS, B. A. (2002) Schools of Thought in Organizational Learning. Journal of the Academy of Marketing Science, 30, 70 - 86.

BESSANT, J., KAPLINSKY, R. \& LAMMING, R. (2003) Putting supply chain learning into practice. International Journal of Operations \& Production Management, 23, 167 184.

BIS (2010) Low Carbon Construction IGT:Final Report. IN DEPARTMENT OF BUSINESS, I. A. S. (Ed.). London, HMSO. 
BLAKE, D., CUCZZA, T. \& RISHI, S. (2003) Now or never: the automotive collaboration imperative. Strategy \& Leadership, 31, 9 - 16.

BOYD, D. \& WILD, A. (2003) Tavistock Studies into the building industry: communications in the building industry (1965) and Interdependence and uncertainty.

IN MURRAY, M. \& LANGFORD, D. (Eds.) Construction Reports 1944 - 98. Oxford, Blackwell Science Ltd.

BRESNEN, M. (2009) Learning to Co-operate and Co-operating to Learn: Knowledge, Learning and Innovation in Construction Supply Chains. IN PRYKE, S. (Ed.) Construction Supply Chain Management Concepts and case studies. Oxford, WileyBlackwell.

BRESNEN, M., EDELMAN, L., NEWELL, S., SCARBROUGH, H. \& SWAN, J. (2005) Exploring social capital in the construction firm. Building Research \& Information, 33, 235 - 244.

CHAN, P., COOPER, R. \& TZORTZOPOULOS, P. (2005) Organizational learning: conceptual challenges from a project perspective. Construction Management and Economics, 23, 747 - 756.

CHERNS, A. \& BRYANT, D. (1984) Studying the Client's Role In Construction Management. Construction Management and Economics, 2, 177 - 184.

CHEVIN, D. (2011) Morrell points the way to 20\% cuts. Construction Manager, 4 - 5.

CHINOWSKY, P., MOLENAAR, K. \& BASTIAS, A. (2007a) Measuring achievement of learning organizations in construction. Engineering, Construction and Architectural Management, 14, 215 - 227.

CHINOWSKY, P., MOLENAAR, K. \& REALPH, A. (2007b) Learning Organizations in Construction. Journal of Management in Engineering, 23, 27 - 34. 
COOPER, M. C. \& ELLRAM, L. M. (1993) Characteristics of Supply Chain Management and the Implications for Purchasing and Logistics Strategy. The International Journal of Logistics Management, 4, 13 - 24.

COX, A. (2004) The art of the possible: relationship management in power regimes and supply chains. Supply Chain Management: An International Journal, 9, 346 - 356.

COX, A., IRELAND, P. \& TOWNSEND, M. (2006) Managing in Construction Supply Chains and Markets, London, Thomas Telford.

CRESPIN-MAZET, F. \& PORTIER, P. (2010) The reluctance of construction purchasers towards project partnering. Journal of Purchasing \& Supply Management, 16, 230 238.

DAINTY, A. R. J., BRISCOE, G. H. \& MILLETT, S. J. (2001) Subcontractor perspectives on supply chain alliances. Construction Management and Economics, 19, 841 - 848.

DAINTY, A. R. J. \& BROOKE, R. J. (2004) Towards improved construction waste minimisation: a need for improved supply chain integration? Structural Survey, 22, 20 $-29$.

DORAN, D. \& GIANNAKIS, M. (2011) An examination of a modular supply chain: a construction sector perspective. Supply Chain Management: An International Journal, 16, $260-270$.

EASTERBY-SMITH, M. \& ARAUJO, L. (1999) Organizational Learning: Current Debates and Opportunities. IN EASTERBY-SMITH, M., BURGOYNE, J. \& ARAUJO, L. (Eds.) Organizational Learning and the Learning Organization: Developments in theory and practice. London, SAGE Publications.

ECCLES, R. G. (1981) The Quasifirm in the Construction Industry. Journal of Economic Behavior and Organization, 2, 335 - 357.

EGAN, J. (1998) Rethinking Construction. DETR. 
ELLEGAARD, C., BYGBALlE, L. E., DUBOIS, A. \& BANKVALL, L. (2010) Guest Editorial Purchasing and Supply Management in the Construction Industry. Journal of Purchasing \& Supply Management, 16, 219 - 220.

FELLOWS, R. (2009) Culture in Supply Chains. IN PRYKE, S. (Ed.) Construction Supply Chain Management: Concepts and Case Studies. Oxford, Wiley-Blackwell.

GARVIN, D. (1993) Building a Learning Organization. Harvard Business Review, 78 - 91.

GOSLING, J., PURVIS, L. \& NAIM, M. M. (2010) Supply chain flexibility as a determinant of supplier selection. International Journal Production Economics, 128, 11 - 21.

GREEN, S. (2011) Making Sense of Construction Improvement, Oxford, Wiley-Blackwell.

GREEN, S., KAO, C.-C. \& LARSEN, G. D. (2010) Contextualist Research:Iterating between Methods While Following an Empirically Grounded Approach. ASCE Journal of Construction Engineering and Management, 136, 117 - 126.

HARTMANN, A. \& CAERTELING, J. (2010) Subcontractor procurement in construction: the interplay of price and trust. Supply Chain Management: An International Journal, 15, $354-362$.

HUBER, G. P. (1991) Organizational learning: The contributing processes and the literatures. Organizational Science, 2, 88 - 115.

KHALFAN, M. M. A. \& MCDERMOTT, P. (2007) Integrated Supply Chain - An Example from the UK Construction Industry. COBRA. Georgia Institute of Technology, RICS.

KING, A. P. \& PITT, M. C. (2009) Supply Chain Management: A Main Contractor's Perspective. IN PRYKE, S. (Ed.) Construction Supply Chain Management Concepts and Case Studies. Oxford, Wiley-Blackwell.

KOHTAMAKI, M. (2010) Relationship governance and learning in partnerships. The Learning Organization, 17, 41 - 57. 
KORCZYNSKI, M. (1996) The Low-Trust Route to Economic Development: Inter-Firm Relations in the UK Engineering Construction Industry in the 1980s and 1990s. Journal of Management Studies, 33, 787 - 808.

KULULANGA, G. K., EDUM-FOTWE, F. T. \& MCCAFFER, R. (2001) Measuring construction contractors' organizational learning. Building Research \& Information, 29, 21 - 29.

KUMARASWAMY, M. M., ANVUUR, A. \& MAHESH, G. (2008) Contractual frameworks and cooperative relationships. IN SMYTH, H. \& PRYKE, S. (Eds.) Collaborative Relationships in Construction developing frameworks \& networks. Oxford, WileyBlackwell.

LEVITT, B. \& MARCH, J. (1988) Organizational Learning. Annual review of Sociology, 14, $319-40$.

LOVE, P., E.D., IRANI, Z., CHENG, E. \& LI, H. (2002) A model for supporting interorganizational relations in the supply chain. Engineering, Construction and Architectural Management, 9, 2 - 15.

LOVE, P., E.D., IRANI, Z. \& EDWARDS, D. J. (2004a) A seamless supply chain management model for construction. Supply Chain Management: An International Journal, 9, 43 - 56.

LOVE, P. E. D., HUANG, J. C., EDWARDS, D. J. \& IRANI, Z. (2004b) Nurturing a learning organization in construction: a focus on strategic shift, organizational transformation, customer orientation and quality centered learning. Construction Innovation, 4, 113 - 126.

LUMMUS, R., R. \& VOKURKA, R., J. (1999) Defining supply chain management: a historical perspective and practical guidelines. Industrial Management \& Data Systems, 99, 11 - 17. 
MARTINEZ-COSTA, M. \& JIMENEZ-JIMENEZ, D. (2009) The Effectiveness of TQM: The Key Role of Organizational Learning in Small Businesses. International Small Business Journal, 27, 98 - 125.

MASON, K. J. \& LEEK, S. (2008) Learning to Build a Supply Network: An Exploration of Dynamic Business Models. Journal of Management Studies, 45, 774 - 799.

MENG, X., SUN, M. \& MARTYN, J. (2011) Maturity Model for Supply Chain Relationships in Construction. Journal of Management in Engineering, April, 97 105.

O'BRIEN, W. J., FORMOSO, C. T., LONDON, K. A. \& VRIJHOEF, R. (2009) Introduction. IN O'BRIEN, W. J., FROMOSO, C. T., VRIJHOEF, R. \& KERRY, L. A. (Eds.) Construction Supply Chain Management Handbook. London, Taylor \& Francis Group.

OLAYINKA, R. \& HEDLEY, S. (2007) Analysis of Types of Continuous Improvement: Demonstration Projects of the Egan and Post-Egan Agenda. COBRA. Atlanta, RICS.

ORANGE, G., CUSHMAN, M. \& BURKE, A. (1999) COLA: a cross-organisational approach within UK industry. 4th International Conference on Networking Entities. Krems, Austria.

ORTON, J., DOUGLAS. (1997) From Inductive to iterative grounded theory: Zipping the gap between process theory and process data. Scandinavian Journal of Management, 13, 419 - 438.

PETERS, L. D., JOHNSTON, W. J., PRESSEY, A. D. \& KENDRICK, T. (2010) Collaboration and collective learning: networks as learning organisations. Journal of Business \& Industrial Marketing, 25, 478 - 484. 
POTTS, K. (2009) From Heathrow Express to Heathrow Terminal 5: BAA's Development of Supply Chain Management. IN PRYKE, S. (Ed.) Construction Supply Chain Management Concepts and Case Studies. Oxford, Wiley-Blackwell.

POWER, D. (2005) Supply chain management integration and implementation: a literature review. Supply Chain Management: An International Journal, 10, 252 - 263.

PRYKE, S. (2009) Introduction. IN PRYKE, S. (Ed.) Construction Supply Chain Management Concepts and Case Studies. Oxford, Wiley-Blackwell.

RICS (2010) Contracts in Use: A Survey of Building Contracts in Use during 2007. London, RICS.

RINGBERG, T. \& REIHLEN, M. (2008) Towards a Socio-Cognitive Approach to Knowledge Transfer. Journal of Management Studies, 45, 912 - 935.

SAAD, M., JONES, M. \& JAMES, P. (2002) A review of the progress towards the adoption of supply chain management (SCM) relationships in construction. European Journal of Purchasing \& Supply Management, 8, 173 - 183.

SEGERSTEDT, A. \& OLOFSSON, T. (2010) Supply Chains in the construction industry. Supply Chain Management: An International Journal, 15, 347 - 353.

SENGE, P. M. (1990) The Fifth Discipline, The Art and Practice of the Learning Organization, London, Century Business.

SILA, I., EBRAHIMPOUR, M. \& BIRKHOLZ, C. (2006) Quality in supply chains: an empirical analysis. Supply Chain Management: An International Journal, 11, 491 502.

SKITMORE, M. \& SMYTH, H. (2009) Marketing and Pricing Strategy. IN PRYKE, S. (Ed.) Construction Supply Chain Management Concepts and Case Studies. Oxford, WileyBlackwell. 
SPEKMAN, R. E., KAMAUFF, J. W. J. \& MYHR, N. (1998) An empirical investigation into supply chain management: A perspective on partnerships. International Journal of Physical Distribution \& Logistics Management, 28, 630 - 650.

SPENDER, J. C. (1996) Organizational knowledge, learning and memory: three concepts in search of a theory. Journal of Organizational Change Management, 9, 63 - 78.

STOCK, J. R. \& BOYER, S. L. (2009) Developing a consensus definition of supply chain management. International Journal of Physical Distribution \& Logistics Management, 39, 690 - 711.

STRINGER, J. (1967) Operational Research for 'Multi-Organizations'. Operational Research Society, 18, $105-120$.

STYHRE, A., JOSEPHSON, P.-E. \& KNAUSEDER, I. (2004) Learning capabilities in organizational networks: case studies of six construction projects. Construction Management and Economics, 22, 957 - 966.

TOMMELEIN, I. D., BALLARD, G. \& KAMINSKY, P. (2009) Supply Chain Management for Lean Project Delivery. IN O'BRIEN, W., J., FORMOSO, C., T., VRIJHOEF, R. \& LONDON, K. A. (Eds.) Construction Supply Chain Management Handbook. London, Taylor and Francis Group.

VRIJHOEF, R. \& KOSKELA, L. (2000) The four roles of supply chain management in construction. European Journal of Purchasing \& Supply Management, 6, 169 - 178.

WESTERLUND, M. \& RAJALA, R. (2010) Learning and innovation in inter-organizational network collaboration. Journal of Business \& Industrial Marketing, 25, 435 - 442.

WOLSTENHOLME, A. (2009) Never waste a good crisis: A review of Progress since Rethinking Construction and Thoughts for Our Future. London, Constructing Excellence in the Built Environment. 
ZENGER, T. R. \& HESTERLY, W. S. (1997) The Disaggregation of Corporations: Selective Intervention, High-powered Incentives, and Molecular Units. Organizational Science, 8, $209-222$. 